\title{
Global Burden of Animal Diseases: a novel approach to understanding and managing disease in livestock and aquaculture
}

\author{
B. Huntington ${ }^{(1,2)}$, T.M. Bernardo ${ }^{(3)}$, M. Bondad-Reantaso ${ }^{(4)}$, M. Bruce ${ }^{(5)}$, \\ B. Devleesschauwer ${ }^{(6,7)}$, W. Gilbert ${ }^{(1)}$, D. Grace ${ }^{(8,9)}$, A. Havelaar ${ }^{(10)}$, \\ M. Herrero ${ }^{(11)}$, T.L. Marsh ${ }^{(12)}$, S. Mesenhowski ${ }^{(13)}$, D. Pendell ${ }^{(14)}$, \\ D. Pigott ${ }^{(15)}$, A.P. Shaw ${ }^{(1,16)}$, D. Stacey ${ }^{(17)}$, M. Stone ${ }^{(18)}$, P. Torgerson ${ }^{(19)}$, \\ K. Watkins ${ }^{(20)}$, B. Wieland ${ }^{(21)} \&$ J. Rushton ${ }^{(1)^{*}}$
}

(1) Department of Livestock and One Health, Institute of Infection, Veterinary and Ecological Sciences, University of Liverpool, 146 Brownlow Hill, Liverpool L3 5RF, United Kingdom

(2) Pengwern Animal Health Ltd, 259 Wallasey Village, Wallasey Wirral, Merseyside CH45 3LR, United Kingdom (3) Department of Population Medicine, Ontario Veterinary College, University of Guelph, 50 Stone Road East, Guelph, Ontario N1G 2W1, Canada

(4) Fisheries and Aquaculture Department, Food and Agriculture Organization of the United Nations, Viale delle Terme di Caracalla, 00153 Rome, Italy

(5) School of Veterinary Medicine, Centre for Animal Production and Health, Murdoch University, 90 South Street, Murdoch, Western Australia 6150, Australia

(6) Department of Epidemiology and Public Health, Sciensano, Rue Juliette Wytsman 14, 1050 Brussels, Belgium

(7) Department of Veterinary Public Health and Food Safety, Ghent University, Salisburylaan 133, 9820 Merelbeke, Belgium

(8) Food and Markets Department, Natural Resources Institute, Faculty of Engineering and Science, University of Greenwich, Chatham Maritime ME4 4TB, United Kingdom

(9) International Livestock Research Institute, P0 Box 30709, Nairobi 00100, Kenya

(10) Animal Sciences Department, Emerging Pathogens Institute, Food Systems Institute, University of Florida, Gainesville, FL 32611, United States of America

(11) CSIRO Agriculture and Food, 306 Carmody Road, St Lucia, Queensland 4067, Australia

(12) Paul G. Allen School for Global Animal Health, Allen Center, School of Economic Sciences, Washington State University, PO Box 647090, 1155 College Avenue, Pullman, Washington 99164, United States of America (13) Bill \& Melinda Gates Foundation, 500 5th Ave N., Seattle, WA 98109, United States of America

(14) Department of Agricultural Economics, Kansas State University, Manhattan, KS 66506, United States of America

(15) Institute for Health Metrics and Evaluation, University of Washington, 2301 5th Avenue, Seattle, WA 98121, United States of America

(16) AP Consultants, 22 Walworth Enterprise Centre, Duke Close, Andover SP10 5AP, United Kingdom

(17) School of Computer Science, University of Guelph, Reynolds Building, 474 Gordon Street, Guelph, Ontario N1G 1Y4, Canada

(18) World Organisation for Animal Health, 12 rue de Prony 75017, Paris, France

(19) Section of Epidemiology, Vetsuisse Faculty, University of Zurich, Winterthurerstrasse 270, 8057 Zürich,

Switzerland

(20) FoodFirst LLC, 630 East 13th Street, Indianapolis, IN 46201, United States of America

(21) International Livestock Research Institute, PO Box 5689, Addis Ababa, Ethiopia

${ }^{*}$ Corresponding author: j.rushton@liverpool.ac.uk

Authors between the first and last authors are in alphabetical order.

\section{Summary}

Investments in animal health and Veterinary Services can have a measurable impact on the health of people and the environment. These investments require a baseline metric that describes the burden of animal health and welfare in order to justify and prioritise resource allocation and from which to measure the impact of interventions. This paper is part of a process of scientific enquiry in which problems are identified and solutions sought in an inclusive way. It poses the broad question: what should a system to measure the animal disease burden on society look like and what value would it add? Moreover, it aims to do this in such a way as to be accessible by a wide audience, who are encouraged to engage in this debate. Given that farmed animals, including those raised by poor smallholders, are an economic entity, this system should be based on economic 
principles. These poor farmers are negatively impacted by disparities in animal health technology, which can be addressed through a mixture of supply-led and demand-driven interventions, reinforcing the relevance of targeted financial support from government and non-governmental organisations. The Global Burden of Animal Diseases (GBADs) Programme will glean existing data to measure animal health losses within carefully characterised production systems. Consistent and transparent attribution of animal health losses will enable meaningful comparisons of the animal disease burden to be made between diseases, production systems and countries, and will show how it is apportioned by people's socio-economic status and gender. The GBADs Programme will produce a cloud-based knowledge engine and data portal, through which users will access burden metrics and associated visualisations, support for decisionmaking in the form of future animal health scenarios, and the outputs of wider economic modelling. The vision of GBADs - strengthening the food system for the benefit of society and the environment - is an example of One Health thinking in action.

\section{Keywords}

Agriculture - Aquaculture - Baseline - Burden - Economics - Gender - Global Burden of Animal Diseases Programme - Investment - Livestock - One Health - Poverty - Women farmers.

\section{Introduction}

Years of investment in the development of frameworks $(1,2)$ for data capture and analysis have allowed estimations of investment in human health, so that today it is possible to find that, in 2017, global human health spending was US\$ 7.8 trillion, equivalent to $10 \%$ of the global gross domestic product (GDP) or US\$1,080 per capita (ranging from US\$ 41 in low-income countries to US\$2,937 in high-income countries) (3). In contrast, while data and information on expenditure for animal health are collected, they are as yet disaggregated, often unavailable or uncertain, and unlikely to be easily accessible. There are estimates that the animal health products market was valued at US\$ 24 billion in 2015, about $2.5 \%$ of the global human health market (4), yet this figure provides little information on the cost of services, or investments into education, coordination and research. Given that animal health is integral to the wellbeing of society, understanding animal health investments is critical to support decision-making and achieve the One Health vision.

In assessing changes in human health, the concept of using health-adjusted life year (HALY) metrics is well established. A number of such metrics have since been developed and used, most notably the quality-adjusted life year (QALY), which was introduced in the 1970s and describes the health benefit in terms of mortality and morbidity for a medical intervention $(5,6)$. Since the 1990s, the Global Burden of Disease (GBD) Study has used the disability-adjusted life year (DALY) to measure health loss in humans, in terms of premature death and changes in the level of disability during the acute, chronic and recovery phases of a disease or health problem (7). This has become a standard used to describe the disease burden in a human population and, although not a monetary metric, is used as an outcome measure for interventions. The GBD Study generates longitudinal estimates that have the power to look at specific targeted actions to change human health, as well as to measure the impacts of policy and investment changes on human health in a more general sense. Through the provision of objective, standardised and therefore comparable information, the human health sector (and in particular the GBD) has redefined the way in which the global community assesses resource mobilisation and allocation to human disease priorities.

There is, as yet, no equivalent, consistently applied, systematic process in animal health, as DALYs do not map so cleanly into measures for animals in a market-based, anthropocentric society. Therefore, both components of the burden of animal health and welfare - losses due to disease and health problems, and expenditure on preventative and reactive measures (hereafter referred to as the burden of animal disease) - are currently inaccessible at the sector, national or global level. This information is required to increase society's understanding of the misallocation of resources across animal production systems, and also within responses to individual animal health issues. The Global Burden of Animal Diseases (GBADs) Programme intends to correct this deficiency through the creation of a standardised international system, which over time will generate the information required to make such estimations. 
Land, water and air resources have significant public good attributes and are used by small- and large-scale producers alike. Livestock (which, throughout this paper, unless qualified, means both terrestrial and aquatic farmed animals) have become dominant on the planet. Research on terrestrial farming has estimated that two-thirds of agricultural land is dedicated to livestock (8); agriculture takes between $70 \%$ and $90 \%$ of the Earth's fresh water (9) and a third of this is used on livestock (10); and livestock are a major source of methane (and, indirectly, carbon dioxide) emissions and local pollution (11). The allocation of resources to healthy, productively efficient animals kept in good welfare conditions is culturally appropriate. Yet, so that this resource allocation does not place an unacceptable opportunity cost on others, due to inefficient or unsustainable resource use, a thorough understanding of this societal issue is needed (12).

\section{Importance of livestock to the smallholder farmer}

The challenges that small- and large-scale farmers face in the global context can, on the one hand, be remarkably similar (for example, the consumption of environmental resources), yet also differ starkly (access to animal health services and technologies). There is disparity in the distribution of animal health systems and infrastructure. A great proportion of livestock are kept in large farms under controlled and intensive conditions (13). These farms are major users of pharmaceutical products. Yet the majority of livestock keepers across the world are small-scale producers. These people are poor and, in many situations, have little access to veterinary services and technologies.

This poor access can be attributed to the lack of funding in many resource-constrained countries. However, in many cases, this is an outcome of market failure that requires societal intervention. For example, lower-income countries have a smaller market and low willingness to pay for products. This means that the high overheads faced by producers of pharmaceutical veterinary products are better met by targeting their development and supply towards the predominant animal health issues in high-income countries, where there is a larger market and increased willingness to pay (14). Availability of these products in low-income countries is not in itself a solution; last-mile distribution network initiatives seek to address the high transaction costs that prevent access to animal health technologies. Sustainable solutions for smallholders must take into account the nuanced socioeconomic roles that livestock play in low- and middleincome countries (15).

\section{Box 1}

The context for the smallholder farmer

The final report of the World Health Organization (WHO) Commission on Social Determinants of Health states, 'Inequity in the conditions of daily lives is shaped by deeper social structures and processes; the inequity is systematic, produced by policies that tolerate or actually enforce unfair distribution of and access to power, wealth, and other necessary social resources' (16). This narrative was continued in a report marking the starting point for the Lancet-University of Oslo Commission on Global Governance for Health, which described power asymmetry as the root cause of inequity (17). Considering that those with power determine animal health systems, the risk of an asymmetry of power translating into an asymmetry of information means that market failures, such as those described above, are inevitable. It is, therefore, of moral significance that asymmetry of information is challenged in order to redistribute power and address inequity in animal health systems.

Explaining the importance of foot and mouth disease (FMD) control to Juanita Perez and her family, who are sheep farmers high in the Bolivian Andes, could certainly leave one questioning whether or not resources are invested wisely. Juanita trades her sheep and their wool at the local markets. What relevance do the Bolivian FMD control strategy and implications for international trade hold for her? It becomes clear that enabling access to and providing advice on nutrition, genetics and parasite control has the potential to have a tangible impact on the productivity of Juanita's flock and the wealth and well-being of her family. It is not wholly surprising that mismatches such as this exist - where well-intentioned policies imposed at the national level, perhaps reflecting a country's ambitions on the regional or global stage, provide little or no support to the daily problems encountered by farmers producing for their own consumption and the local market.

Women like Juanita, and the families and flocks they support, play crucial roles in human nutrition and health and in society as a whole, providing income, food, clothing, building materials, fertiliser, fuel and draught power. Across the world, 1.3 billion people are directly dependent on food animals for their livelihoods, of whom 600 million, such as Juanita, are smallholder farmers in some of the world's poorest countries (18). The health of their animals is under constant pressure from communicable and non-communicable animal diseases; inadequate access to feed, forage and clean water; injuries; and predation. For these vulnerable people, poor animal health leads directly to poverty and malnutrition, exposure to zoonotic disease risk, poor health and reduced welfare. Aside from the animal keepers, unhealthy animals themselves suffer. At the global level, the lower productivity of diseased animals contributes to climate change and environmental degradation, as more resources are required to produce a unit of output.

Understanding the context for smallholder farmers and others on the margins of society re-emphasises the moral need to address the information asymmetry in animal health systems. A standardised process to understand the burden across the whole of society, which is applied in a consistent and transparent way, is an essential part of the solution. 
This paper poses the question: what should a system to measure the burden of animal disease look like and what value will it add to Veterinary Services? It is, after all, their role to mitigate the health and welfare issues of animals that provide food, fibre, manure, draught power and a source of investment. As well as supplying important social and cultural benefits, the livestock sector is fundamentally an economic activity; hence this paper presents livestock production as an economic process. The paper will summarise the use of economics in animal health, drawing on important theories from the literature. It will provide an explanation of how economics can be used to understand and address private (farm-level) and public (societal-level) costs. This information will be gathered to detail the steps needed to integrate physical science with economic theory, in order to ask important questions for the animal health sector at the societal level.

The framework presented is applicable across all levels, from the individual farmer and his or her household to the agri-food sector, as well as at the national level and globally. Once institutionalised, the longitudinal estimates generated will help to guide the allocation of resources to major problems and allow the evaluation of animal health programmes. The urgency of such work has never been greater, with the rise in the proportion of human diseases coming from animals (19), the greater frequency of disease outbreaks (20), the potential scale of the impact of an emerging zoonotic disease that becomes transmissible among humans (e.g. COVID-19) and the role of livestock in climate change.

The system proposed will accurately describe the role of animals in society and the importance of managing animal health and welfare. Moreover, it will improve our ability to explain how activity in the animal health system can support the achievement of economic, social, public health, food security and environmental goals. It is based on an understanding of the need to make the best use of the available data; to describe gaps that need to be filled, and to use logical frameworks to systematically generate credible and useful information. The system must create clarity for decision-making in a complex world.

\section{The use of economics in animal health}

Farmers use formal and informal budgeting methods to allocate their scarce resources. Historically, these have been the basis of the emergence of farm-level micro-economics (21). Important lessons are also drawn from present-day, small- and large-scale farmers who routinely use well-tested farm-budgeting methods and multi-criteria decision tools to evaluate their enterprises and plan for the future. By investing resources in veterinary care and management advice, farmers demonstrate an understanding that providing for their animals' health and welfare will underpin the success of their business. However, rarely is the evidence available to understand the relative contributions of interventions to control different diseases, as compared to, for instance, resources spent on improving the quality of the animals' housing, feed or water.

A collaboration between colleagues J. McInerney and K. Howe in the 1980s led to early work on the use of economic principles for animal health $(22,23)$. A framework emerged (24), and McInerney presented a seminal paper on the economics of animal health to the Society of Agricultural Economics in 1996 (25). McInerney described the multifaceted effects of animal disease on the food system (Fig. 1); modelled input/output relationships in the presence and absence of disease, explaining disease losses as a 'genuinely economic variable'; and extended this framework to describe a disease loss-expenditure frontier, explaining that 'optimal management is concerned with reducing to its lowest level the cost incurred due to disease' (Fig. 2a). $\mathrm{He}$ proposed areas for development: notably, improving information on disease losses, particularly as they extend downstream in the food chain, and their impacts on trade and disease control, particularly in regard to expenditure on veterinary medicines and services in the pursuit of disease treatment, prevention or eradication. Thus, an economic assessment of the burden of animal diseases must extend to the investigation of private and public costs throughout the food system.

Tisdell (26) extended McInerney's theory by exploring models for optimising disease control for more than one disease, and relaxing McInerney's example of strict concavity of the benefit function from controlling disease (Fig. 2a). Tisdell introduced curves that mirror those of McInerney by comparing benefits - as opposed to costs against expenditure, and describing a break-even point for the benefits realised from expenditure on disease control (Fig. 2b). In some cases, these S-shaped curves predict no benefit from expenditure before exceeding a threshold level. The curve that Tisdell describes is analogous to those used to explain the poverty trap (Fig. 2c), a concept that was originally championed by Sachs and retold by Banerjee and Duflo $(27,28)$, based on ideas described in a series of texts from the mid-20th century $(29,30,31,32,33)$. A poverty trap exists when income today is insufficient for a person or family to afford, for example, education, healthcare or animal health technologies, resulting in a future in which their income is even lower. The S-shaped curve describes how this situation will result in impoverished people in the poverty trap zone becoming poorer over time. These people will not move out of this zone without outside support. 


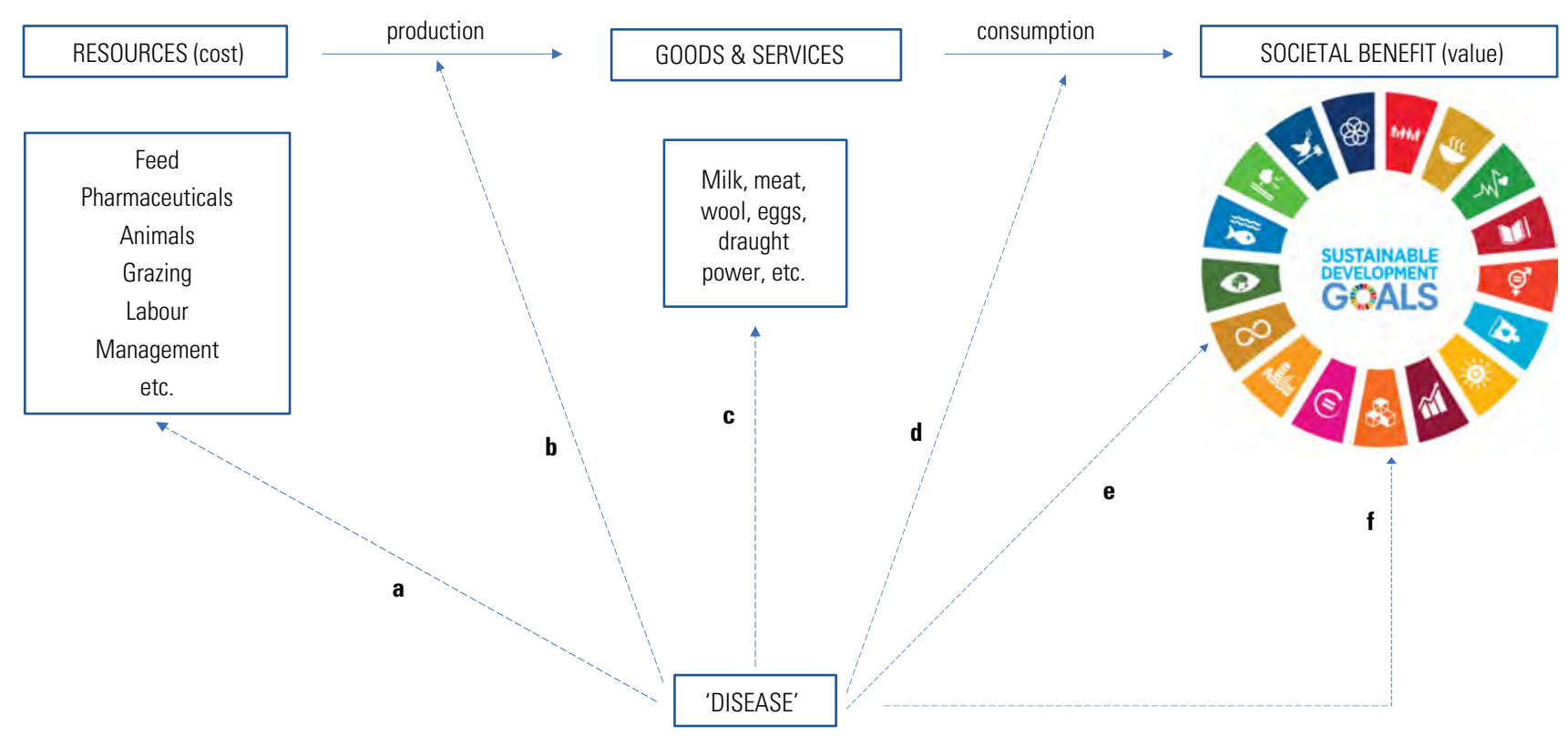

Disease is a particular class of negative influences in the value-creating process that uses livestock as economic resources. Its negative effects are most widely recognised in the production sector of livestock farming and arise because it:

a) destroys the basic resources (mortality of breeding or productive animals)

b) lowers the efficiency of the production process and the productivity of resources used (reduced rates of growth or feed conversion)

c) reduces the realised physical output of the production process or its unit value (lowered milk yield or quality).

A broader view of the food system recognises that animal disease can also:

d) lower the suitability of livestock products for processing, or generate additional costs in the distribution chain (drug residues, meat inspection)

e) affect human well-being directly (through zoonoses such as Salmonella and brucellosis).

Finally, there are:

f) an array of more diffuse negative economic effects which reduce the total value that a society gains from livestock. These range from constraints on trade in animal products to the reduction in consumption benefits, or even outright negative benefit, that people experience when the awareness of a disease (e.g. bovine spongiform encephalopathy) changes their image of a food product. Added to this are the utility reductions (i.e. reduced satisfaction from consumption) felt by people who associate animal disease with poor animal welfare.

\section{Fig. 1}

Livestock production is an economic process and is subject to the negative influences of disease Adapted from McInerney (25)

The question of whether disease and sub-optimal productivity of livestock contribute to a poverty trap for poor smallholder farmers is an important one. If this is the case, and if a threshold expenditure on animal health - which is more than poor people can afford - is needed to see sustained and meaningful income from livestock, continued government and non-governmental organisation (NGO) support in the form of grants or loans will be essential to achieve societal benefits from livestock farmed by poor people. However, if this poverty trap is not real, and other socio-economic factors are not limiting, a demand-driven, more equitable, private supply of animal health services and technologies can support these small-scale producers to improve the health and productivity of their animals, thus contributing to their own wealth and well-being.

This threshold expenditure is a combination of the cost of establishing an available service and the cost of the service at the point of delivery. Ahuja (34) explains that, while evidence exists that poor farmers are willing to pay market price for assured and good-quality veterinary services, market failures exist, and it is the role of the state to address these. Recognising the role of local NGOs in channelling government funds and generating demand for veterinary services, Ahuja states that: 'government has the additional responsibility of nurturing the development process in a way that empowers the farmers to demand quality services'. In a technical paper presented to the 84th General Session of the World Organisation for Animal Health (OIE), Rushton and Gilbert (35) explain how animal health policy can become a mix of demand-driven responses and, where market failure exists, supply-led responses to address poor resource allocation. They conclude that the evidence base for policy decisions needs to be improved.

In considering the need to supplement poor, small-scale farmers' expenditure on animal disease control with outside financial support (from the state or otherwise), this debate 

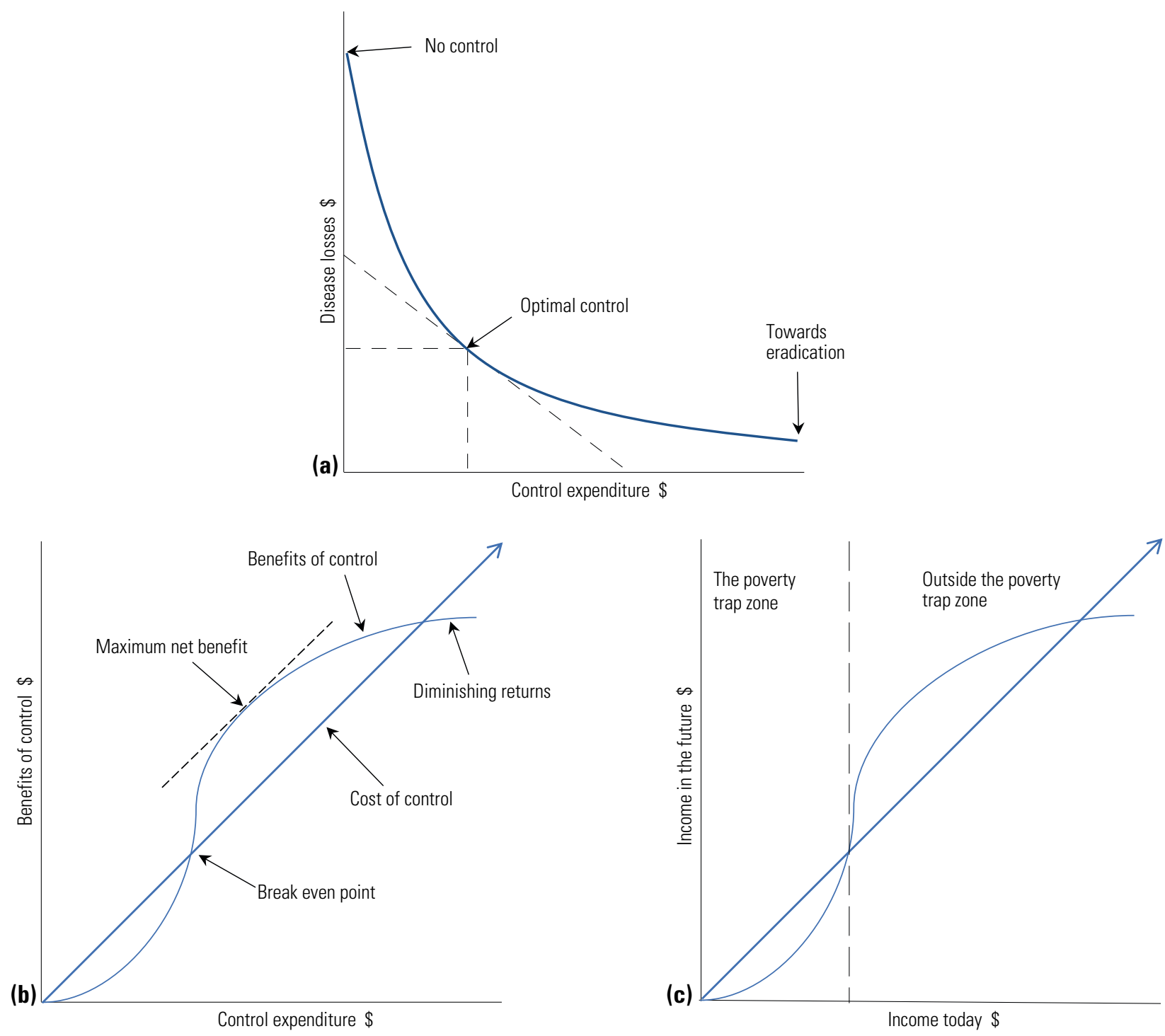

Fig. 2

The Disease Loss-Expenditure Frontier (a), relaxing strict concavity of the benefit function from controlling disease (b), and drawing parallels with the Poverty Trap (c) to highlight the requirement for supply-led as well as demand-driven responses in equitable provision of animal health services

Adapted from Mclnerney (a) (25), Tisdell (b) (26) and Banerjee and Duflo (c) (27)

takes place within the wider scope of the policy arena. Not only will individual animal diseases be vying for a proportion of the animal health spend but, more crucially, the total animal health spend will be determined alongside the state's spend on infrastructure, human health, education and defence, to name but a few examples.

A large and valuable volume of work has been produced by a community of economists and epidemiologists who have, over time, become comfortable working hand in hand, providing practical support for farming operations of all scales and advice to governments on policy. This community is well represented by the International Society for Veterinary Epidemiology and Economics (ISVEE), the International Society for Economics and Social Sciences of Animal Health and, in the United Kingdom, the Society for Veterinary Epidemiology and Preventive Medicine. The OIE has commissioned two editions of the Scientific and Technical Review on the economics of animal health, edited by Perry in 1999 (36) and Rushton in 2017 (37). The wider agricultural economics literature is also fertile ground, particularly for studies examining the wider economic (public) costs of animal diseases. 
These important bodies of work have tackled the issue of suitable approaches for private and public costs of animal disease control (38), provided useful, practical overviews of analytical methods (39), and challenged the heuristic nature of the decision-making process at the national policy level (35). This last aspect is arguably the most important, when considering the change in paradigm that is required to take an objective societal view on animal disease control.

Economics in animal health has traditionally been used as an adjunct to advocacy for reducing or eliminating a specific pathogen in a population (Fig. 3) (40). Partial budget analyses, cost-benefit analyses of specific issues, crisis response ('fire-fighting') and heuristics (rules of thumb to simplify and speed up decision making) have driven the investment agenda. Instead, the authors favour an approach that searches for optimal solutions in resource allocation, driving evidence-based decision-making and improving productivity and human well-being (Fig. 3).

\section{Turning theory into practice at the policy level - building blocks}

In his 1996 presentation to the Society of Agricultural Economics, McInerney stated:

'The complexity we can add to the core (economic) model does not obscure its fundamental validity as a representation of the real world - indeed, it is the complexity that illuminates it.' (25)

\section{An animal health approach}

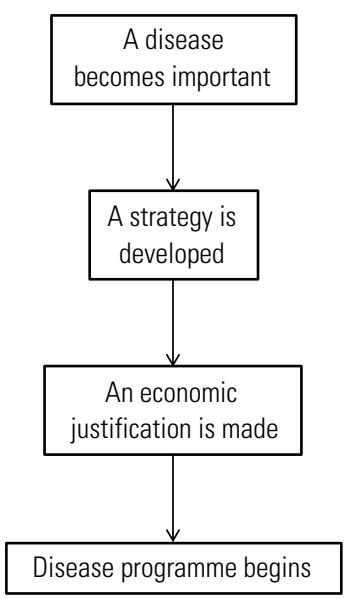

An economic approach

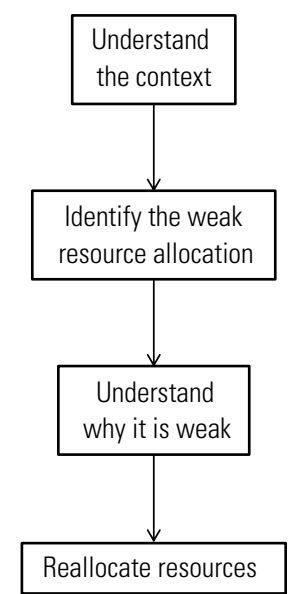

Fig. 3

An economic versus animal health approach

Adapted from Rushton (40)
The application of the economic approach relies on a crucial first step: understanding the context. A multidisciplinary approach is required to carefully and successfully disentangle the apparent complexity of the food system into bite-sized portions. Future publications are planned which will elaborate on research methods and provide examples of early outputs for critique.

\section{Populations and production systems, biomass and value}

The baseline data needed to characterise livestock and production systems (including their productivity levels) in different parts of the world have seldom been available at the level of disaggregation necessary to make informed decisions on disease prioritisation, the upscaling potential of key interventions, and their impacts on productivity and household nutrition, income and the empowerment of women. The role of women in these systems is often emphasised but the value of their work is rarely adequately quantified. By describing the value of their work in economic terms, the GBADs Programme will lay the foundation for generating information on animal health problems that affect women, as well as indicating where women have ownership and control over livestock.

Isolated examples relying on painstaking manual data collation do exist (41), and more recent studies have benefited from access to new data sources $(42,43)$. As a result, some coherent building blocks are emerging $(44,45)$. In some specific areas, detailed pieces of work are starting to provide information on the potential for productivity increases in the small-scale producer setting $(46,47)$.

Outputs of these exercises include (at the production-system level) an appreciation of population numbers, including age and sex structure, weights and prices (live animals for breeding and further production, and finished animals). Rothman-Ostrow et al. (48) explore alternatives to the use of the tropical livestock unit for biomass measurement, and provide refined estimates of cattle biomass that take into account data on breed, live weight and herd structures. Updated, accurate biomass estimates, based on a sound understanding of livestock population dynamics, are essential to ensure that greenhouse gas (GHG) emissions estimates are a true representation $(49,50)$.

Further investment in the collation of accurate baseline data, allowing us to refine our understanding of biomass and capital investments in livestock, will provide an important starting point to: create business cases for investment in animal health, determine the (re-)allocation of resources, and improve estimations of GHG emissions from the livestock sector. 


\section{Measuring animal health loss}

The pros and cons of applying a HALY approach to losses caused by disease in animals are discussed in Shaw et al. (51) and Torgerson et al. (52). The DALY metric was founded on general concepts presented by Murray (7). These ideas point towards a moral conviction that all human lives are of equal value and notably include the choice to restrict the characteristics of an individual affected by a health outcome to age and sex only. Ultimately, as livestock are an economic entity, a monetary measure is most appropriate. However, adjustments may be needed to reflect local, per-capita gross national product (GNP), and thus to measure the actual impact of animal diseases on livestock owners (52). There are further important lessons that can be derived from the successful GBD Study, notably the first general concept proposed by Murray: 'To the extent possible, any health outcome that represents a loss of welfare should be included in an indicator of health status' (7).

This extends the concept of human health problems beyond disease impacts to include other causes of poor health from nutrition, mental health, and accidents and injuries - indeed any that society will use resources to avert. In this way, the HALY approach does translate to GBADs and shapes two important ground rules:

1. All possible causes of the animal disease burden should be considered - not only notifiable/transboundary diseases or those historically viewed as 'important', but also including (and not limited to) endemic and non-communicable diseases, nutritional issues, injuries and accidents, as well as the impacts of poor animal husbandry practices.

2. To capture the burden of animal disease, an appreciation of the enterprise budget is required. Livestock output encapsulates all entries and exits of animals, while enterprise costs reflect other productivity indices, such as feed conversion and veterinary expenditure, as well as spending on infrastructure, including biosecurity measures. Using the enterprise budget as a basis will ensure that all losses associated with animal health (or disease) can be considered while, at the same time, preventing overstatement of the effects of individual diseases.

By collating data on input and output relationships, the animal health losses for specified production systems can be modelled as a function of the current enterprise budget, compared with a defined, transparent, and consistently applied utopian situation, which need not necessarily be based on empirical data. This is analogous to the GBD, where the human disease burden is estimated as a loss of healthy life expectancy, compared to an idealised healthy life expectancy with no loss due to disease or injury (53). But with animals, rather than using life expectancy, it is necessary to use an idealised system where there are no losses due to disease, injury or inadequate nutrition. It is important to appreciate that, while this idealised situation may seem unachievable to the producer, its primary purpose is to facilitate the methodological framework, creating a total boundary on losses that cannot be exceeded at the attribution stage.

\section{Animal health ontology and attribution}

The GBADs Programme relies on a massive volume of data from multiple data sources, including scientific articles published in journals, national animal censuses, electronic farm and agribusiness records, and agriculture statistics curated by the World Health Organization (WHO), the Food and Agriculture Organization of the United Nations (FAO) and the OIE. These data sets display considerable heterogeneity in their methodological design and descriptors (54), creating a challenging environment in which to use this information to make meaningful comparisons - for example, between diseases in various production systems and different countries - in a consistent and transparent way.

\section{Ontology for flexible classification}

Ontologies are frameworks comprising concepts and their relationships that are interpretable by both humans and computers, within a structured vocabulary. Ontologies play an important role in knowledge and data standardisation to support data integration, sharing, reproducibility and analysis. Components of the ontology tool for GBADs will incorporate: animal demography, specific disease aetiologies or syndromes, measure(s) of severity, and associated effects on production. Ontologies can incorporate existing resources but require agreed classification standards as a basis for true integration and interoperability (55). In this context, the ontology will be integrated with the OIE's codification of animal health electronic data, resulting in interoperability with other existing international health terminologies and information systems.

Establishing ontologies, vocabularies, and an associated knowledge graph will enable complex reasoning about the data being provided by all participants and will supply modellers with information about the quality of their data. The model's representation of the real-world situation can be improved by integrating feedback from end users, leveraging a dynamic process to enhance relevance and reliability.

\section{Attribution}

In his paper, 'The application of economics in animal health programmes: a practical guide', which appeared in volume 18 (2) of the Scientific and Technical Review, Morris explained: 
'Economic analysis is not a form of financial accounting; the main concern in economics is to rank alternative disease control measures in order of the merit of each alternative, hence to make the best decision, and not to calculate the exact monetary value. Thus, although imperfect data is often used in many analyses, this does not necessarily reduce the value of the results.' (39)

The task of prioritising animal health intervention strategies must be informed by quantitative assessments of the burden of disease from specific causes. Thus, the first methodological step in estimating animal health loss by cause is to determine the 'envelope' that contains losses and expenditure due to individual diseases, health issues and injuries. Adapting methodology developed for the GBD $(53,56)$, the animal health loss envelope is then divided into specific causes (such as specific pathogens, syndromes or accidents), with components of the animal disease burden, such as production loss, expenditure on disease mitigation and market effects, attributed to their causes and identifying their associated risk factors.

In extensive livestock systems, where data may be sparse or unvalidated (57), we can harness the principles of ontology, adopt them to make the best use of diverse untapped data sources, and accept (as Morris explains in the quote above [39]) that analyses based on imperfect data can still be of great value for decision-makers, for whom information on the relative importance of a specific disease or intervention is often as important as the absolute. In other words, sometimes the ranking order, not the impeccability of the data, is the important thing. Through a process of structured discovery, data strengths and weaknesses can be systematically described and the marginal benefits of closing specific data gaps evaluated.

\section{Using economic analyses to guide equitable investment prioritisation}

Economic analysis of the impact of disease on domestic and international markets can produce rich - and valuable decision-making criteria for the individual household up to the policy-maker. The information that methods such as cost-benefit analysis and cost-effectiveness analysis produce creates a powerful resource for decision-makers, but it is important that this power is part of the solution not the problem. A systematically applied framework producing widely (and freely) available information has the advantage of reducing asymmetries in information and hence decision-making power.
The classical animal health approach (Fig. 3) is driven by structures that place decision-making power in the hands of veterinarians who provide expert opinion on the importance of disease and the subsequent control strategy. Conversely, the economic approach (Fig. 3) can be a vehicle for a more equitable distribution of power. For this approach to be successful, it must be based on a thorough understanding of the drivers of disease outcomes and the production systems in which they act. It requires that economic approaches be developed with input from a wide range of participants throughout the value chain. A range of alternative interventions should be identified, across which changes in benefits and the costs of the disease burden can be measured (58). Considering the impact on all economic agents throughout the value chain, including the consumer, is a requirement of any complete, objective, economic evaluation of a food system. This is key to identifying the net benefits that stakeholders, governments, and society receive, and the costs incurred, from the disease burden, interventions, and policies or regulations. A range of models (partial equilibrium, input-output, budgeting) have been used to understand the impact of disease - in its simplest form, an output supply constraint - on the agriculture sector, regional non-agricultural sector and government spending (59). Models can be extended to include a temporal aspect, tracking changes in producer and consumer welfare over time.

By providing this information, the GBADs Programme will support evidence-based investment plans for animal health systems, and improve our understanding of the marginal gains to society that can be made from investments in animal health. Figure 4 describes how GBADs will be a natural adjunct to the OIE's Performance of Veterinary Services (PVS) Pathway, including the Gap Analysis component. Information that disaggregates the burden of animal diseases by the type of farmers and consumers affected, and also addresses the gender balance of the burden, will allow the allocation of resources to key social, economic and environmental problems, strengthening PVS outcomes. The GBADs Programme and PVS metrics will work in conjunction to support high-quality evaluations of existing animal health investments and, in doing so, will demonstrate the value of animal health systems.

A strength of the GBADs Programme is in the foundations that have been built both through the evolving work described above, and specifically by the development of a theoretical - and practical - framework during a thorough development phase (2018-2020) (60). The steps described above will provide the necessary contextual information on the animal disease burden to identify weak resource allocations in specific production systems and describe how this impacts the wider economy. This baseline information will provide the ground work for the systematic application of analytical methods to support decisions. 


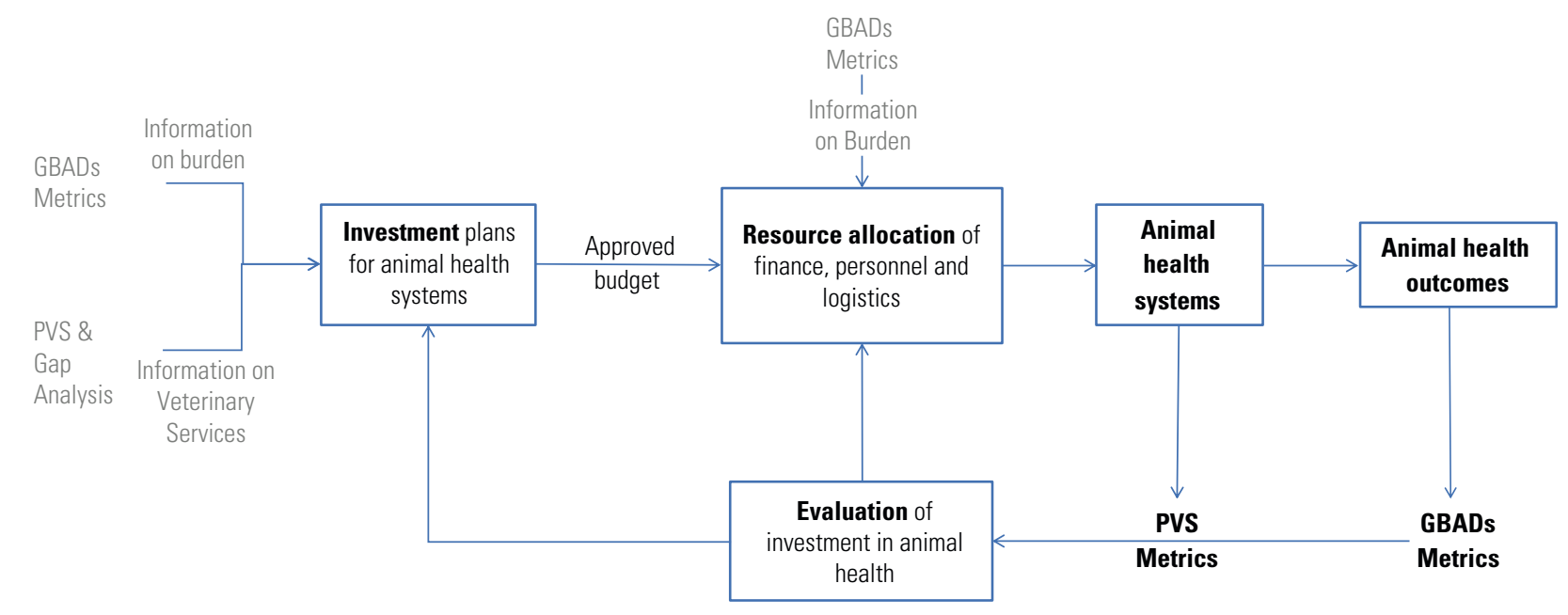

GBADs: $\quad$ Global Burden of Animal Diseases

PVS: $\quad$ Performance of Veterinary Services

Fig. 4

The Global Burden of Animal Diseases: supporting the investment cycle

\section{Joining the blocks together}

\section{Engagement}

For the GBADs Programme to function, the building blocks described above must be linked together so that data can be acquired, analysed and interacted with. For GBADs to add value, this process must be relevant, credible and useful. 'Hitting the mark' in these aspects will be crucial to the GBADs Programme's long-term success and must be founded on thoughtful engagement with the public and private sectors, intermediary beneficiaries (e.g. policymakers) and end users (e.g. farmers) to understand their values and needs. Those who value GBADs will more readily supply the data to feed the analyses and respond to close gaps in data availability, accessibility or quality. A survey conducted in 2019 of more than 150 key animal health decision-makers across governments, NGOs and the private sector provided evidence that an operational GBADs system would create an increased willingness to share animal health data; and over 90\% of respondents said they would use GBADs analysis to support decision-making (61). Further work is planned to understand the values of the end users that drive their decisions, with a particular emphasis on the role and empowerment of women at the individual farm level.

\section{Informatics}

Modern technology provides the potential to readily harness the wealth of data that exists in the animal health and production domains. Learning from the best current examples, while acknowledging emerging trends and technologies, will ensure that GBADs meets the needs of its users now and into the future. The vision for the user interface of GBADs is a cloud-based knowledge engine composed of:

- diverse data sources

- open application programming interfaces (APIs), which specify the interactions that are possible with a software component, such as a database, program or web application

- dynamic, open-source models applying GBADs methods for analyses

- tools that enhance the findability, accessibility, interoperability and re-use of data on animal diseases and their burdens.

A modern knowledge engine and data portal must also take into account issues such as data provenance and the ethical impact of the use of data on diverse communities (not just the GBADs community). In particular, as technological methods allow for data ingestion from mobile devices, indigenous communities around the globe may take part in local data gathering (and even data analysis and modelling). To ensure that the appropriate ethical guidelines are followed, the GBADs Programme will take a number of standards into consideration, such as:

- guidelines for accurate and transparent health estimates reporting (GATHER), to disclose how human health estimates are developed (62)

- meeting principles of findability, accessibility, interoperability and reusability (FAIR), and extending this to include security (D. Stacey, K. Wulff, N. Chikhalia \& T.M. Bernardo, unpublished data)

- the CARE principles (collective benefit, authority to control, responsibility, ethics) for indigenous data governance (63). 
This knowledge engine will maximise the use of existing data from a variety of sources, both public and private, at the global, national, sector and project levels, providing new insights and improved functionality, and enabling collaborators to find meaning in and formulate evidence from these data.

\section{Global Burden of Animal Diseases and human health}

The GBD and WHO Global Burden of Foodborne Disease estimates (64) describe human health outcomes associated with zoonotic and foodborne diseases. Furthermore, they include information on animal population demographics in modelling processes that recognise animal factors as covariates for human health outcomes. For those zoonotic and foodborne disease estimates that are already included in these global initiatives, GBADs will provide an opportunity to supplement the existing models with additional data and updated evidence. For those foodborne and zoonotic diseases that are conspicuous in their absence as human health outcomes, the GBADs data collation process will support their future inclusion in global human health work. Over all, the GBADs Programme will provide a mechanism to understand the potential for zoonotic diseases to emerge from livestock, thereby supporting the development of surveillance and prevention actions to manage and limit the risks of disease emergence.

\section{The food system - an example of One Health in action}

Through the complementary use of resources (e.g. feed, manure) and services (draught power), animal and plant health are part of a linked economic process. Together they are part of a food system that supports society and contributes to the attainment of the United Nations' Sustainable Development Goals (Fig. 5) (65). In this context, GBADs supports the development of the framework for the Global Burden of Crop Loss (66).

Future activities will support decision-making from the One Health perspective in areas of antimicrobial use and resistance, and human nutrition. Important associations are yet to be fully explored between antimicrobial use in humans and animals and antimicrobial resistance patterns in these populations, and also the environment. Detailed data from food systems - data sets which not only identify production constraints and access to alternative food sources but also collate information on micronutrient availability

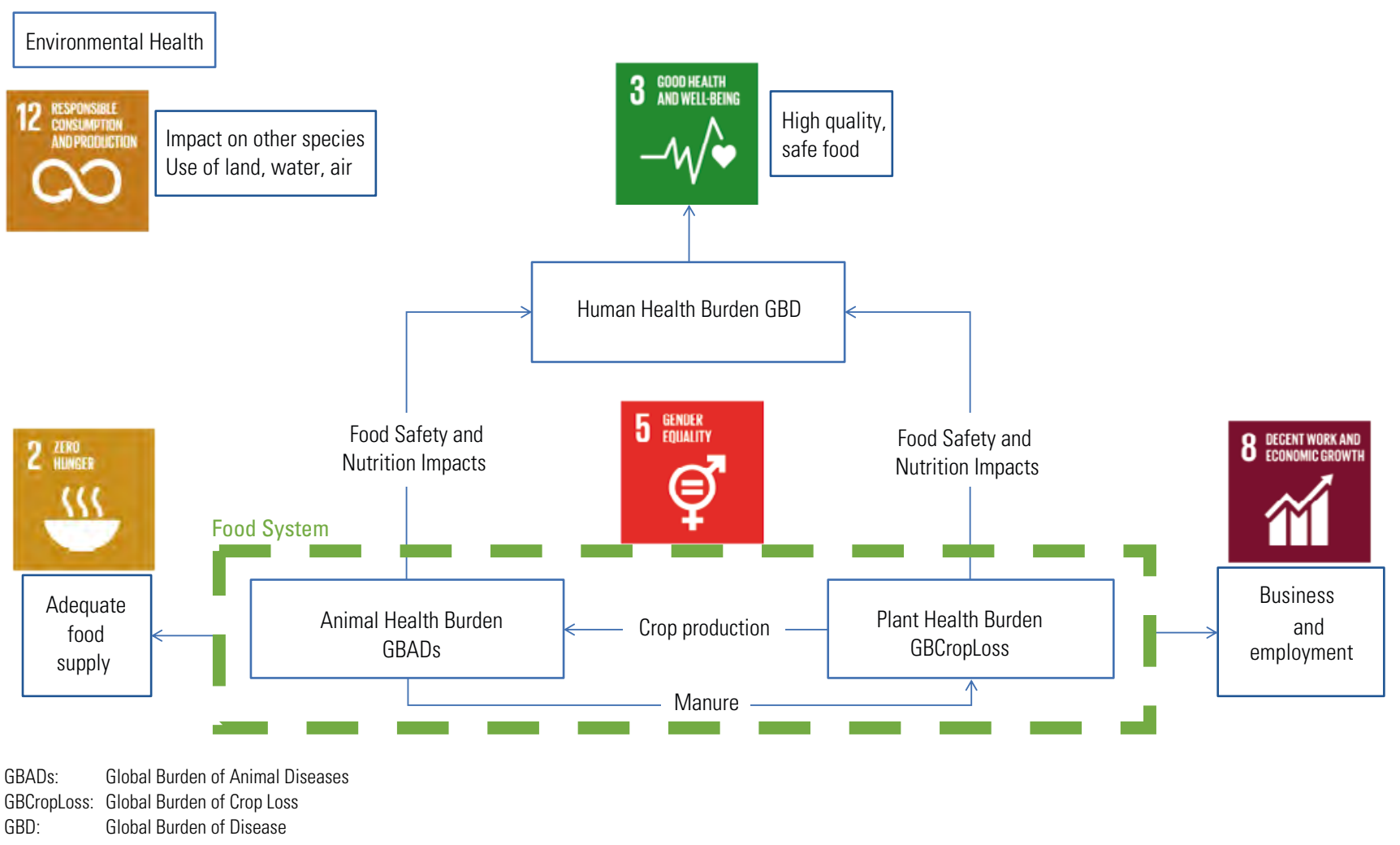

Fig. 5

The Global Burden of Animal Diseases as part of a One Health approach that addresses the United Nations Sustainable Development Goals (67) 
from different meat sources and carcass components will enhance already established food production and consumption models.

\section{Conclusions}

The GBADs Programme will provide essential baseline information on the social, economic and environmental burden of animal diseases. It will address the needs of keepers of livestock and aquatic animals, consumers and the environment by supporting investment plans, which ensure that there are adequate animal health systems; the allocation of resources to problems that most affect animal health and well-being; and evaluations of animal health investments to ensure that they are delivering good societal outcomes.

Food safety, nutritional impacts, and existing and emerging zoonotic pathogens in farmed animals all present challenges and opportunities. Both must be addressed to provide highquality, safe food to alleviate the human health burden. In this context, GBADs will partner with global initiatives in human health (GBD, WHO) and plant health (Global Burden of Crop Loss). All those involved in the food system must be aware of the impact it has, both in terms of the welfare and diversity of farmed species it relies on, and the wildlife on which it undoubtedly has direct and indirect effects (67). The food system is a major consumer of land and water resources; it produces, and can capture, environmental pollutants. Therefore, as society strives for means to ensure a responsible and sustainable impact on the globe's natural resources, a food system supported by evidence-based decision-making is more important now than ever.

\section{Acknowledgements}

The authors would like to acknowledge the valuable contributions of David Adamson, João Afonso, Peter Ballantyne, Camille Bellet, David Brodbelt, Paula CaceresSoto, Hannah Davies, Nicoline de Haan, Alexis Delabouglise, Matthew Ferrari, Simon Firestone, Jane Gibbens, Marius Gilbert, Barbara Häsler, Robert Jakob, Olga Jonas, Vivek Kapur, Joe Lane, Timos Lanitis, Tim Leyland, David McIver, Dianne Mayberry, Sumiko Mekaru, Shannon Mesenhowski, Anna Okello, Walter Okello, Brian Perry, Marisa Peyre, Julio Pinto, Didier Raboisson, Tom Randolph, Karl Rich, Timothy Robinson, Jaime Romero, Peregrine RothmanOstrow, Jeremy Salt, Emily Tagliaro, Peter Tozer, Mark Van Wijk, William Wint, Paul Wood and Panagiotis Zervas.

The Global Burden of Diseases programme has received funding from the Bill \& Melinda Gates Foundation; the Foreign, Commonwealth and Development Office of the United Kingdom; and the Australian Centre for International Agricultural Research.

\title{
L'impact mondial des maladies animales: une nouvelle approche pour mieux comprendre et gérer les maladies affectant le bétail et l'aquaculture
}

\author{
B. Huntington, T.M. Bernardo, M. Bondad-Reantaso, M. Bruce, \\ B. Devleesschauwer, W. Gilbert, D. Grace, A. Havelaar, M. Herrero, \\ T.L. Marsh, S. Mesenhowski, D. Pendell, D. Pigott A.P. Shaw, D. Stacey, \\ M. Stone, P. Torgerson, K. Watkins, B. Wieland \& J. Rushton
}

\section{Résumé}

Les investissements réalisés en santé animale et dans les Services vétérinaires ont un impact mesurable sur la santé des personnes et de l'environnement. Le système de mesure appliqué à ces investissements doit reposer sur un référentiel de base décrivant l'impact de la santé et du bien-être animal de manière à justifier et classer par priorités les ressources allouées et à mesurer les effets des interventions. Les auteurs présentent une étude conduite dans le cadre d'une enquête scientifique destinée à identifier les problèmes et à rechercher des solutions de manière inclusive. L'étude pose la question de savoir à quoi devrait ressembler un système conçu pour mesurer l'impact sur 
la société des maladies animales, et quelle serait sa valeur ajoutée. En outre, l'étude est conduite de manière à être accessible à une large audience afin d'encourager cette dernière à participer aux discussions. Étant donné que les animaux d'élevage constituent une entité économique, y compris les animaux appartenant à des éleveurs pauvres, le système de mesure doit reposer sur des principes économiques. Les exploitants pratiquant une agriculture de subsistance subissent les effets négatifs des disparités entre les différentes technologies applicables à la santé animale, disparités auxquelles il est possible de remédier par le biais d'interventions associant des mesures dictées par l'offre et par la demande et en renforçant l'efficacité du soutien financier ciblé apporté par les organisations gouvernementales et non gouvernementales. Le Programme "L'impact mondial des maladies animales " (GBADs) aura pour tâche de glaner les données existantes afin de mesurer les pertes associées à la santé animale au sein de systèmes de production qui auront été soigneusement caractérisés au préalable. Grâce à l'élucidation cohérente et transparente des pertes imputables à chaque problème de santé animale, des comparaisons pertinentes pourront être effectuées concernant l'impact des maladies animales par maladies, par systèmes de production et par pays, et la répartition de cet impact dans les populations concernées suivant le statut socio-économique et le genre des intéressés sera mieux comprise. Le Programme GBADs entend créer un moteur de recherche et un portail de données qui seront disponibles sur le Cloud et donneront aux utilisateurs l'accès à des outils de mesure de l'impact des maladies et à d'autres informations présentées sous forme graphique, ainsi qu'à des outils d'aide à la décision sous forme de scénarios prospectifs sur la santé animale et aux résultats d'études plus larges de modélisation économique. La vision du GBADs - renforcer le système de production de denrées alimentaires au profit de la société et de l'environnement - est un exemple de mise en œuvre du concept Une seule santé.

\title{
Mots-clés
}

Agricultrices - Agriculture - Aquaculture - Bétail - Économie - Genre - Impact Investissement - Pauvreté - Programme " L'impact mondial des maladies animales " Référentiel de base - Une seule santé.

-

\section{El impacto global de las enfermedades animales, como nuevo planteamiento para aprehender y manejar las enfermedades en la ganadería y la acuicultura}

\author{
B. Huntington, T.M. Bernardo, M. Bondad-Reantaso, M. Bruce, \\ B. Devleesschauwer, W. Gilbert, D. Grace, A. Havelaar, M. Herrero, \\ T.L. Marsh, S. Mesenhowski, D. Pendell, D. Pigott A.P. Shaw, D. Stacey, \\ M. Stone, P. Torgerson, K. Watkins, B. Wieland \& J. Rushton
}

\section{Resumen}

Las inversiones en sanidad animal y en los Servicios Veterinarios pueden tener un efecto mensurable en la salud de las personas y el medio ambiente. Para efectuar estas inversiones se precisan parámetros que describan y cuantifiquen la situación de partida y el impacto de los problemas de sanidad y bienestar animales, a fin de poder, a partir de ahí, justificar y jerarquizar la asignación de recursos y medir los efectos de las intervenciones. Este artículo, inscrito en un 
proceso de indagación científica encaminado a detectar problemas y buscar soluciones de forma incluyente, plantea la cuestión general de cómo debería ser y qué valor añadido aportaría un sistema destinado a medir el impacto que imponen a la sociedad las enfermedades animales. Los autores, además, tratan de exponer la cuestión de manera que sea accesible a un público amplio, al que se alienta a participar en este debate. Dado que los animales de granja (incluidos los de pequeñas explotaciones) constituyen una entidad económica, tal sistema debería estar basado en principios económicos. Los productores que trabajan en régimen de subsistencia se ven negativamente afectados por las disparidades existentes en materia de tecnología zoosanitaria, disparidad que cabe corregir con una combinación de intervenciones marcadas por la oferta y otras marcadas por la demanda, dirigiendo así más selectivamente el apoyo económico de entidades gubernamentales y organizaciones no gubernamentales. El programa GBADs (El impacto global de las enfermedades animales) servirá para compilar datos ya existentes con el fin de medir las pérdidas zoosanitarias dentro de sistemas productivos cuidadosamente caracterizados. La atribución coherente y transparente de estas pérdidas zoosanitarias permitirá efectuar comparaciones significativas del impacto que representan las enfermedades animales en el caso de diferentes dolencias, sistemas productivos o países y pondrá de relieve cómo se distribuye este impacto en función del género y la condición socioeconómica de las personas. Por medio del programa GBADs se creará un motor de conocimiento y portal de datos ubicado en la nube que permita al usuario acceder a mediciones del impacto de enfermedades y representaciones gráficas conexas, a herramientas de apoyo a la adopción de decisiones, en forma de hipotéticas situaciones zoosanitarias futuras, y a los resultados de modelizaciones económicas más generales. La aspiración del programa GBADs - reforzar el sistema alimentario en beneficio de la sociedad y el medio ambiente - constituye un ejemplo de aplicación en la práctica del pensamiento en clave de Una sola salud.

\section{Palabras clave}

Acuicultura - Agricultoras-productoras - Agricultura - Economía - Ganado - Género - Impacto - Inversión - Pobreza - Programa «El impacto global de las enfermedades animales» - Situación de partida - Una sola salud.

\section{References}

1. Organisation for Economic Co-operation and Development (OECD) (2000). - A system of health accounts. OECD Publishing, Paris, France, 208 pp. doi:10.1787/9789264181809-en.

2. Organisation for Economic Co-operation and Development (OECD), Eurostat \& World Health Organization (WHO) (2017). - A system of health accounts 2011: revised edition. OECD Publishing, Paris, France, 520 pp. doi:10.1787/9789264270985-en.

3. World Health Organization (WHO) (2019). - Global spending on health: a world in transition. WHO/HIS/HGF/HFWorkingPaper/19.4. WHO, Geneva, Switzerland, 68 pp. Available at: www.who.int/health_financing/documents/health-expenditure-report-2019.pdf?ua=1 (accessed on 30 January 2021).

4. HealthforAnimals (2015). - Global benchmarking survey 2015: benchmarking the competitiveness of the global animal health industry. HealthforAnimals, Brussels, Belgium, 36 pp. Available at: healthforanimals.org/150-global-benchmarking-survey-2015-report.html (accessed on 30 January 2021)

5. Fanshel S. \& Bush J.W. (1970). - A health-status index and its application to health-services outcomes. Oper. Res., 18 (6), 1021-1066. doi:10.1287/ opre.18.6.1021.

6. Bush J.W., Fanshel S. \& Chen M.M. (1972). - Analysis of a tuberculin testing program using a health status index. Socioecon. Plann. Sci., 6 (1), 49-68. doi:10.1016/0038-0121(72)90006-7. 
7. Murray C.J.L. (1994). - Quantifying the burden of disease: the technical basis for disability-adjusted life years. Bull. WHO, 72 (3), 429-445. Available at: apps. who.int/iris/handle/10665/264057 (accessed on 6 August 2021).

8. Wirsenius S., Azar C. \& Berndes G. (2010). - How much land is needed for global food production under scenarios of dietary changes and livestock productivity increases in 2030? Agric. Syst., 103 (9), 621-638. doi:10.1016/j.agsy.2010.07.005.

9. Molden D. (ed.) (2007). - Water for food, water for life: a comprehensive assessment of water management in agriculture. Earthscan, London, United Kingdom; \& International Water Management Institute, Colombo, Sri Lanka, 640 pp. Available at: hdl.handle.net/10568/36463 (accessed on 30 January 2021)

10. Gerbens-Leenes P.W., Mekonnen M.M. \& Hoekstra A.Y. (2013). - The water footprint of poultry, pork and beef: a comparative study in different countries and production systems. Water Resour. Indust., 1-2, 25-36. doi:10.1016/j.wri.2013.03.001.

11. Steinfeld H., Gerber P.J., Wassenaar T., Castel V., Rosales M. \& de Haan C. (2006). - Livestock's long shadow: environmental issues and options. Food and Agriculture Organization of the United Nations, Rome, Italy, 416 pp. Available at: www.fao.org/3/a070le/a070le.pdf (accessed on 30 January 2021).

12. Ostrom E. (1990). - Governing the commons: the evolution of institutions for collective action. Cambridge University Press, Cambridge, United Kingdom. doi:10.1017/CBO9780511807763.

13. Herrero M., Thornton P.K. [...] \& Havlík P. (2017). - Farming and the geography of nutrient production for human use: a transdisciplinary analysis. Lancet Planet. Hlth, 1 (1), e33-e42. doi:10.1016/S2542-5196(17)30007-4.

14. Tisdell C.A. \& Adamson D. (2017). - The importance of fixed costs in animal health systems. In The economics of animal health (J. Rushton, ed.) Rev. Sci. Tech. Off. Int. Epiz., 36 (1), 49-56. doi:10.20506/rst.36.1.2608.

15. Herrero M., Grace D., Njuki J., Johnson N., Enahoro D., Silvestri S. \& Rufino M.C. (2013). - The roles of livestock in developing countries. Animal, 7 (Suppl. 1), 3-18. doi:10.1017/S1751731112001954.

16. World Health Organization (WHO) Commission on Social Determinants of Health (2008). - Closing the gap in a generation: health equity through action on the social determinants of health: final report of the Commission on Social Determinants of Health. WHO, Geneva, Switzerland, 246 pp. Available at: apps.who.int/iris/bitstream/handle/10665/43943/9789241563703_eng.pdf?sequence=1\&isAllowed=y (accessed on 31 May 2021).

17. Ottersen O.P., Dasgupta J. [...] \& Scheel I.B. (2014). - The political origins of health inequity: prospects for change. Lancet, 383 (9917), $630-667$. doi:10.1016/S0140-6736(13)62407-1.

18. Thornton P.K., Jones P.G. [...] \& Kulkar U. (2006). - Mapping climate vulnerability and poverty in Africa. International Livestock Research Institute, Nairobi, Kenya, 200 pp. Available at: hdl.handle.net/10568/2307 (accessed on 30 January 2021).

19. Cleaveland S., Laurenson M.K. \& Taylor L.H. (2001). - Diseases of humans and their domestic mammals: pathogen characteristics, host range and the risk of emergence. Philos. Trans. Roy. Soc. Lond. B, Biol. Sci., 356 (1411), 991-999. doi:10.1098/rstb.2001.0889.

20. Patterson G.T., Thomas L.F., Coyne L.A. \& Rushton J. (2020). - Moving health to the heart of agri-food policies; mitigating risk from our food systems. Glob. Food Secur., 26, 100424. doi:10.1016/j.gfs.2020.100424.

21. Backhouse R.E. (2004). - The ordinary business of life: a history of economics from the ancient world to the twenty-first century. Princeton University Press, Princeton, United States of America, 384 pp. Available at: press.princeton.edu/books/paperback/9780691116297/the-ordinarybusiness-of-life (accessed on 3 September 2020).

22. Howe K.S. (1985). - An economist's view of animal disease. In Proc. Society for Veterinary Epidemiology and Preventive Medicine (M.V. Thrusfield, ed.), 27-30 March, Reading, United Kingdom. Society for Veterinary Epidemiology and Preventive Medicine, 122-129.

23. McInerney J.P. (1987). - An economist's approach to estimating disease losses. In Diseases in farm livestock: economics and policy (agriculture) (K.S. Howe \& J.S. McInerney, eds). Commission of the European Communities, Brussels, Belgium, 25-60.

24. McInerney J.P., Howe K.S. \& Schepers J.A. (1992). - A framework for the economic analysis of disease in farm livestock. Prev. Vet. Med., 13 (2), 137-154. doi:10.1016/0167-5877(92)90098-Z.

25. Mclnerney J. (1996). - Old economics for new problems - livestock disease: presidential address. J. Agric. Econ., 47 (1-4), 295-314. doi:10.1111/j.1477-9552.1996.tb00695.x.

26. Tisdell C. (1995). - Assessing the approach to cost-benefit analysis of controlling livestock diseases of McInerney and others. Working Paper No. 3. Research papers and reports in animal health economics: an ACIAR Thai-Australian project. University of Queensland, Brisbane, Australia, 19 pp. doi:10.22004/ag.econ.164425. 
27. Banerjee A.V. \& Duflo E. (2011). - Poor economics: rethinking poverty and the ways to end it. Penguin Random House India, Gurugram, India, 320 pp.

28. Sachs J. (2005). - The end of poverty: economic possibilities for our time. Penguin Books, New York, United States of America, 416 pp.

29. Rosenstein-Rodan P.N. (1943). - Problems of industrialisation of Eastern and South-Eastern Europe. Econ. J., 53 (210-211), 202-211. doi:10.2307/2226317.

30. Nurkse R. (1952). - Some international aspects of the problem of economic development. Am. Econ. Rev., 42 (2), $571-583$.

31. Scitovsky T. (1954). - Two concepts of external economies. J. Polit. Econ., 62 (2), 143-151. doi:10.1086/257498.

32. Leibenstein, H. (1957). - Economic backwardness and economic growth: studies in the theory of economic development. John Wiley \& Sons, New York, United States of America, 319 pp.

33. Hirschman A.O. (1958). - The strategy of economic development. Yale University Press, New Haven, United States of America, 230 pp.

34. Ahuja V. (2004). - The economic rationale of public and private sector roles in the provision of animal health services. In Veterinary institutions in the developing world: current status and future needs (C. de Haan, ed.). Rev. Sci. Tech. Off. Int. Epiz., 23 (1), 33-45. doi:10.20506/rst.23.1.1464.

35. Rushton J. \& Gilbert W. (2016). - The economics of animal health: direct and indirect costs of animal disease outbreaks. In Proc. 84th General Session of the World Organisation for Animal Health (OIE), 22-27 May, Paris, France. OIE, Paris, France. doi:10.20506/TT.2551.

36. Perry B.D. (ed.) (1999). - The economics of animal disease control. Rev. Sci. Tech. Off. Int. Epiz., 18 (2), 561 pp.

37. Rushton J. (ed.) (2017). - The economics of animal health. Rev. Sci. Tech. Off. Int. Epiz., 36 (1), 384 pp.

38. Pritchett J., Thilmany D. \& Johnson K. (2005). - Animal disease economic impacts: a survey of literature and typology of research approaches. Int. Food Agribus. Manag. Rev., 8 (1), 1-23.

39. Morris R.S. (1999). - The application of economics in animal health programmes: a practical guide. Rev. Sci. Tech. Off. Int. Epiz., 18 (2), 305-314. doi:10.20506/rst.18.2.1173.

40. Rushton J. (2017). - Improving the use of economics in animal health - challenges in research, policy and education. Prev. Vet. Med., 137 (Pt B), 130-139. doi:10.1016/j.prevetmed.2016.11.020.

41. Rushton J. \& Viscarra R. (2004). - Livestock production systems in South America: analysis and trends. Report for a study on livestock production systems in South America for FAO. Food and Agriculture Organization of the United Nations, Rome, Italy, 33 pp.

42. Henderson B., Godde C., Medina-Hidalgo D., van Wijk M., Silvestri S., Douxchamps S., Stephenson E., Power B., Rigolot C., Cacho O. \& Herrero M. (2016). - Closing system-wide yield gaps to increase food production and mitigate GHGs among mixed crop-livestock smallholders in sub-Saharan Africa. Agric. Syst., 143, 106-113. doi:10.1016/j.agsy.2015.12.006.

43. Herrero M., Havlík P., Valin H., Notenbaert A., Rufino M., Thornton P., Blümmel M., Weiss F., Grace D. \& Obersteiner M. (2013). - Biomass use, production, feed efficiencies, and greenhouse gas emissions from global livestock systems. Proc. Natl. Acad. Sci. U.S.A., 110 (52), $20888-20893$. doi:10.1073/pnas.1308149110.

44. Gilbert M., Nicolas G., Cinardi G., Van Boeckel T.P., Vanwambeke S.O., Wint G.R.W. \& Robinson T.P. (2018). - Global distribution data for cattle, buffaloes, horses, sheep, goats, pigs, chickens and ducks in 2010. Sci. Data, 5, 180227. doi:10.1038/sdata.2018.227.

45. van Wijk M., Hammond J. [...] \& Yameogo V. (2020). - The rural household multiple indicator survey, data from 13,310 farm households in 21 countries. Sci. Data, 7, 46. doi:10.1038/s41597-020-0388-8.

46. Mayberry D., Ash A., Prestwidge D., Godde C.M., Henderson B., Duncan A., Blummel M., Ramana Reddy Y. \& Herrero M. (2017). - Yield gap analyses to estimate attainable bovine milk yields and evaluate options to increase production in Ethiopia and India. Agric. Syst., 155, 43-51. doi:10.1016/j.agsy.2017.04.007.

47. Mayberry D., Ash A., Prestwidge D. \& Herrero M. (2018). - Closing yield gaps in smallholder goat production systems in Ethiopia and India. Livest. Sci., 214, 238-244. doi:10.1016/j.livsci.2018.06.015.

48. Rothman-Ostrow P., Gilbert W. \& Rushton J. (2020). - Tropical livestock units: re-evaluating a methodology. Front. Vet. Sci., 7, 556788. doi:10.3389/ fvets.2020.556788. 
49. Gerber P.J., Steinfeld H., Henderson B., Mottet A., Opio C., Dijkman J., Falcucci A. \& Tempio G. (2013). - Tackling climate change through livestock: a global assessment of emissions and mitigation opportunities. Food and Agriculture Organization of the United Nations, Rome, Italy, 139 pp. Available at: www.fao.org/3/i3437e/i3437e.pdf (accessed on 30 January 2021).

50. Mayberry D., Bartlett H., Moss J., Davison T. \& Herrero M. (2019). - Pathways to carbon-neutrality for the Australian red meat sector. Agric. Syst., 175 (44), 13-21. doi:10.1016/j.agsy.2019.05.009.

51. Shaw A.P.M., Rushton J., Roth F. \& Torgerson P.R. (2017). - DALYs, dollars and dogs: how best to analyse the economics of controlling zoonoses. In The economics of animal health (J. Rushton, ed.). Rev. Sci. Tech. Off. Int. Epiz., 36 (1), 147-161. doi:10.20506/rst.36.1.2618.

52. Torgerson P.R., Rüegg S., Devleesschauwer B., Abela-Ridder B., Havelaar A.H., Shaw A.P.M., Rushton J. \& Speybroeck N. (2018). - zDALY: an adjusted indicator to estimate the burden of zoonotic diseases. One Hlth, 5, 40-45. doi:10.1016/j.onehlt.2017.11.003.

53. GBD 2017 Risk Factor Collaborators (2018). - Global, regional, and national comparative risk assessment of 84 behavioural, environmental and occupational, and metabolic risks or clusters of risks for 195 countries and territories, 1990-2017: a systematic analysis for the Global Burden of Disease Study 2017. Lancet, 392 (10159), 1923-1945. doi:10.1016/S0140-6736(18)32225-6.

54. Afonso J.S., Bruce M., Keating P., Raboisson D., Clough H., Oikonomou G. \& Rushton J. (2020). - Profiling detection and classification of lameness methods in British dairy cattle research: a systematic review and meta-analysis. Front. Vet. Sci., 7, 542. doi:10.3389/fvets.2020.00542.

55. Dórea F.C. \& Vial F. (2016). - Animal health syndromic surveillance: a systematic literature review of the progress in the last 5 years (2011-2016). Vet. Med. (Auckl.), 7, 157-170. doi:10.2147/VMRR.S90182.

56. Mathers C.D., Lopez A.D. \& Murray C.J.L. (2006). - The burden of disease and mortality by condition: data, methods, and results for 2001. In Global burden of disease and risk factors (A.D. Lopez, C.D. Mathers, M. Ezzati, D.T. Jamison \& C.J. Murray, eds). World Bank, Washington, DC, United States of America. Available at: www.ncbi.nlm.nih.gov/books/NBK11808/ (accessed on 26 November 2020).

57. Rushton J. (2009). - The economics of animal health and production. CABI, Wallingford, United Kingdom. doi:10.1079/9781845931940.0000.

58. Marsh T.L., Pendell D. \& Knippenberg R. (2017). - Animal health economics: an aid to decision-making on animal health interventions - case studies in the United States of America. In The economics of animal health (J. Rushton, ed.). Rev. Sci. Tech. Off. Int. Epiz., 36 (1), $137-145$. doi:10.20506/rst.36.1.2617.

59. Pendell D.L., Marsh T.L., Coble K.H., Lusk J.L. \& Szmania S.C. (2015). - Economic assessment of FMDv releases from the National Bio and Agro Defense Facility. PLoS One, 10 (6), e0129134. doi:10.1371/journal.pone.0129134.

60. Rushton J., Bruce M., Bellet C., Torgerson P., Shaw A., Marsh T., Pigott D., Stone M., Pinto J., Mesenhowski S. \& Wood P. (2018). - Initiation of Global Burden of Animal Diseases Programme. Lancet, 392 (10147), 538-540. doi:10.1016/S0140-6736(18)31472-7.

61. Watkins K.L., Rutten-Ramos S. \& Huntington B. (2020). - Modeling broiler industry loss to estimate the value potential of tracking the global burden of animal diseases [abstract 88]. In Poultry Science Association (PSA) 109th Annual Meeting: Abstracts, 20-22 July, Champaign, United States of America, 45 pp. Available at: poultryscience.org/files/galleries/2020-PSA-Abstracts.pdf (accessed on 29 September 2020).

62. Stevens G.A., Alkema L. [...] \& the GATHER Working Group (2016). - Guidelines for accurate and transparent health estimates reporting: the GATHER statement. PLoS Med., 13 (6), el002056. doi:10.1371/journal.pmed.1002056.

63. Research Data Alliance International Indigenous Data Sovereignty Interest Group (2019). - CARE principles for indigenous data governance. Global Indigenous Data Alliance. Available at: www.gida-global.org/care (accessed on 30 January 2021).

64. Havelaar A.H., Kirk M.D. [...] \& Devleesschauwer B. (2015). - World Health Organization global estimates and regional comparisons of the burden of foodborne disease in 2010. PLoS Med., 12 (12), el001923. doi:10.1371/journal.pmed.1001923.

65. United Nations (UN) (2015). - Transforming our world: the 2030 Agenda for Sustainable Development. UN, New York, United States of America, 41 pp. Available at: sustainabledevelopment.un.org/post2015/transformingourworld/publication (accessed on 29 September 2020).

66. Finegold C., Ried J., Denby K. \& Gurr S. (2019). - Global burden of crop loss [poster] [version 1; not peer reviewed]. Gates Open Res., 3, 1599. doi:10.21955/gatesopenres.1116448.1.

67. Osofsky S.A. (2019). - The global burden of (how we manage) animal disease: learning lessons from southern Africa. J. Wildl. Dis., 55 (4), 755-757. doi:10.7589/2019-01-024. 
